\title{
Design, Synthesis, and Biochemical Evaluation of New Triazole Derivatives as Aurora-A Kinase Inhibitors
}

\author{
Omeima Abdullah (ID
}

check for updates

Citation: Abdullah, O. Design,

Synthesis, and Biochemical

Evaluation of New Triazole Derivatives as Aurora-A Kinase Inhibitors. Molecules 2021, 26, 5678. https://doi.org/10.3390/

molecules 26185678

Academic Editor: Pascal Marchand

Received: 26 August 2021

Accepted: 14 September 2021

Published: 18 September 2021

Publisher's Note: MDPI stays neutra with regard to jurisdictional claims in published maps and institutional affiliations.

Copyright: (C) 2021 by the author. Licensee MDPI, Basel, Switzerland. This article is an open access article distributed under the terms and conditions of the Creative Commons Attribution (CC BY) license (https:/ / creativecommons.org/licenses/by/ $4.0 /)$.
College of Pharmacy, Umm Al-Qura University, Makkah 21955, Saudi Arabia; oaabdullah@uqu.edu.sa

\begin{abstract}
Aurora-A kinase, a key mitosis regulator, is expressed in a cell cycle-dependent manner and has an essential role in maintaining chromosomal stability and the normal progression of the cell through mitosis. Aurora-A kinase is overexpressed in many malignant solid tumors, such as breast, ovarian, colon, and pancreatic cancers. Thus, inhibiting Aurora-A kinase activity is a promising approach for cancer treatment. Here, new triazole derivatives were designed as bioisosteric analogues of the known inhibitor JNJ-7706621. The new compounds showed interesting inhibitory activity against Aurora-A kinase, as attested by $\mathrm{IC}_{50} \mathrm{~s}$ in the low to submicromolar range.
\end{abstract}

Keywords: cancer; Aurora-A; kinase; triazole

\section{Introduction}

Most types of cancers are characterized by genomic instability, which can range from subtle DNA sequence changes to gene amplification, chromosome translocations, and alterations in chromosome numbers [1,2]. Chromosome changes are generally referred to by the general term chromosomal instability. Chromosome stability depends on AuroraA kinase, a member of the serine/threonine kinase family and a key mitosis regulator. Aurora-A kinase is expressed in a cell cycle-dependent manner and has an essential role in maintaining chromosomal stability and the normal progression of the cell through mitosis [3]. Aurora-A kinase is overexpressed in many malignant solid tumors, such as breast, ovarian, colon, and pancreatic cancers [4]. For this reason, inhibiting Aurora-A kinase activity is a promising approach for cancer treatment [5]. One compound, JNJ7706621 (Figure 1), is an inhibitor of aurora kinases and of cyclin-dependent kinases [6]. JNJ-7706621 has shown potent antiproliferative activity in various cancerous cell lines and was several folds less potent at inhibiting normal cell growth [7]. Furthermore, it significantly reduced the tumor size in an A375 melanoma human tumor xenograft model [7]. Recently, NJ-7706621 promoted the reversal of resistance to CD37-targeted radioimmunotherapy in DLBC lymphoma cell lines [8]. In the present study, we report the synthesis of JNJ-7706621 analogues (1). These derivatives were designed using an isosteric approach where the amide bond of JNJ-7706621 is replaced by a sulfonamide function (Figure 1). The sulfonamide group was chosen in this study as it is considered highly druggable thanks to its improved stability to hydrolysis and hydrogen bonding potential [9].<smiles>Nc1nc(Nc2ccc(S(N)(=O)=O)cc2)nn1C(=O)c1c(F)cccc1F</smiles>

JNJ-7706621<smiles>[R]c1ccc(S(=O)(=O)n2nc(Nc3ccc(S(N)(=O)=O)cc3)nc2N)cc1</smiles>

(1)
Figure 1. Chemical structure of JNJ-7706621 and its designed bioisosteric analogues (1). 


\section{Results and Discussion}

\subsection{Chemistry}

The compounds (1a-d) were obtained as shown in Figure 2. Briefly, the known triazole derivative (5) was synthesized as previously described [10], with slight modifications. First, 4-aminobenzensulfonamide (2) was heated in a sealed tube with diphenyl cyanocarbonimidate (3) at $90{ }^{\circ} \mathrm{C}$ to give intermediate (4). The latter was then cyclized by treatment with hydrazine to yield derivative $1 \mathrm{H}[1,2,4]$ triazole-3,5-diamine (5). Finally, the desired analogues were obtained by nucleophilic substitution of the corresponding phenylsulfonyl chlorides by the triazole derivative (5) using pyridine as a solvent.

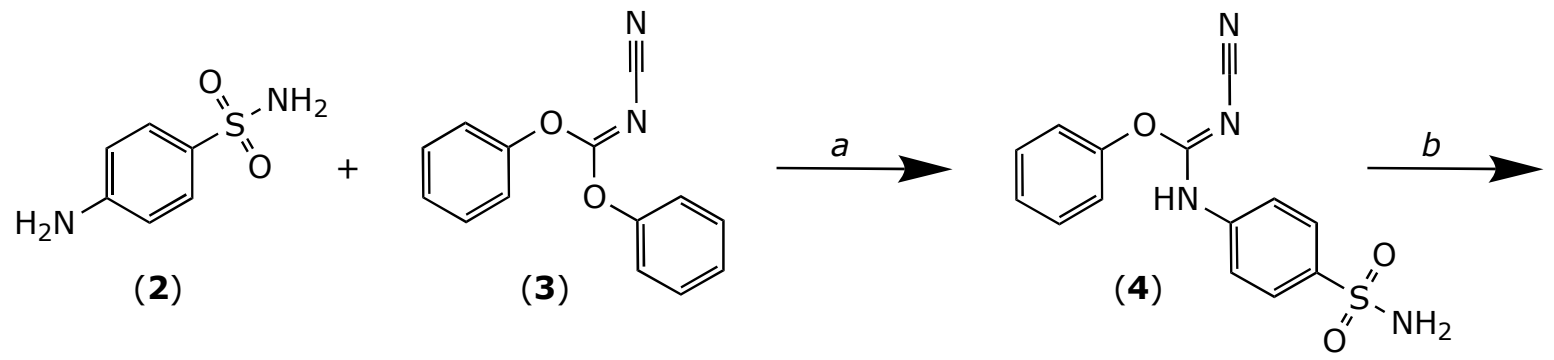<smiles>Nc1n[nH]c(Nc2ccc(S(N)(=O)=O)cc2)n1</smiles><smiles>CCCCC</smiles>

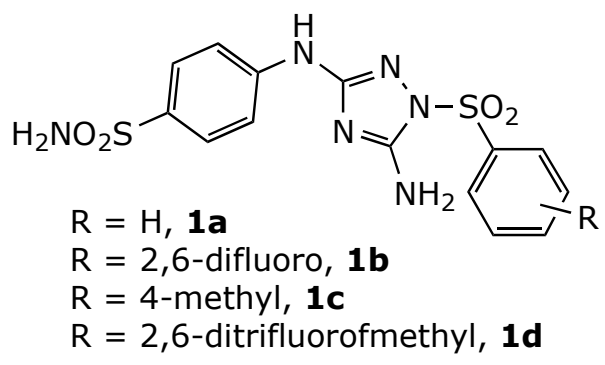

Figure 2. Chemical synthesis of compounds 1a-d. Reagents and conditions: (a) iPrOH, heated in a sealed tube at $90{ }^{\circ} \mathrm{C}, 3 \mathrm{~h}$. (b) $\mathrm{NH}_{2} \mathrm{NH}_{2}$, THF, RT, 12 h. (c) Pyridine, substituted sulfonyl chlorides, RT, overnight.

\subsection{Biological Evaluation}

The inhibition of Aurora-A kinase activity by the designed compounds (Table 1) was evaluated by a method that involved the chelation-enhanced fluorescence mechanism (ChEF-based assay, PhosphoSens ${ }^{\circledR}$ ) [11]. Compounds 1a-c inhibited the kinase activity of Aurora-A kinase with submicromolar $\mathrm{IC}_{50} \mathrm{~s}$. However, the derivatives $\mathbf{1 a}-\mathbf{c}$ were tenfold less active compared to the reference compound JNJ-7706621. The electron-donating nature of the phenyl substituents does not seem to have an important effect on the inhibitory activity, since no significant difference was noted between non-substituted (1a), difluoro (1b), and methyl derivatives (1c). Nevertheless, the bulky trifluoromethyl group seems to cause unfavorable steric interactions.

\subsection{Molecular Modeling}

To obtain a better understanding of the differences in Aurora-A kinase inhibition by JNJ-7706621 versus its sulfonamide analogues, the compounds were docked in silico to the enzyme active site. All the compounds showed close affinity scores compared to JNJ-7706621, <-8.0 kcal/mol. Commensurate with JNJ-7706621, 1b interacted with key amino acids of ATP binding site, Val-147, Lys-141, Glu 260, Leu 263, and Leu-139). Nevertheless, $\mathbf{1 b}$ showed only one H-bond, with Ala-213, in contrast to JNJ-7706621 which displayed two H-bonds with Ala-213 and with Glu-211, both of which were reported as essential for optimal anti-Aurora-A kinase activity [12], Figure 3A,B. Moreover, the bulky trifluoromethyl groups of $\mathbf{1 d}$ changed the orientation of the external acidic sulfonamide away from the hinge region, affecting its interaction with Ala-213 and with Glu-211, Figure 3C. 
Table 1. Inhibitory activity of the developed compounds against Aurora-A kinase.

\begin{tabular}{|c|c|c|c|}
\hline Compound & $X$ & $\mathbf{R}$ & $\mathrm{IC}_{50}(\mu \mathrm{M})^{1}$ \\
\hline JNJ-7706621 & $\mathrm{CO}$ & 2,6-difluoro & $0.016 \pm 0.00$ \\
\hline $1 a$ & $\mathrm{SO}_{2}$ & $\mathrm{H}$ & $0.13 \pm 0.06$ \\
\hline $1 b$ & $\mathrm{SO}_{2}$ & 2,6-difluoro & $0.21 \pm 0.02$ \\
\hline 1c & $\mathrm{SO}_{2}$ & $4-\mathrm{Me}$ & $0.23 \pm 0.02$ \\
\hline $1 d$ & $\mathrm{SO}_{2}$ & 2,6-ditrifluoromethyl & $1.78 \pm 0.34$ \\
\hline
\end{tabular}

${ }^{1}$ Data are presented as Mean \pm SEM of 3 independent experiments.

A

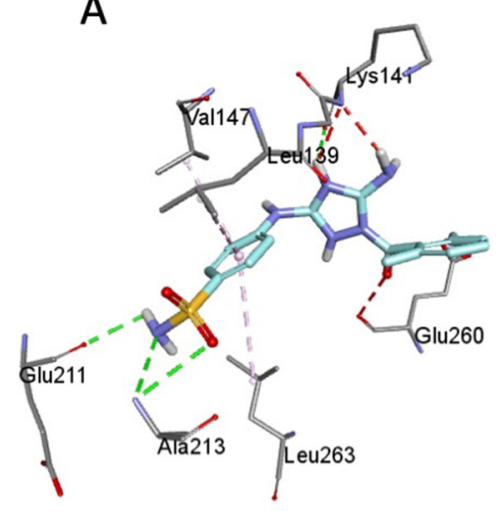

B

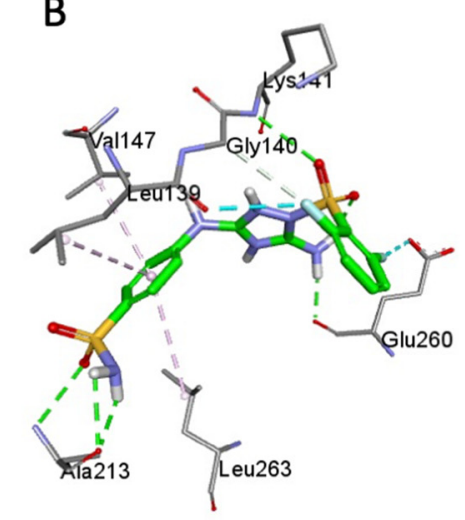

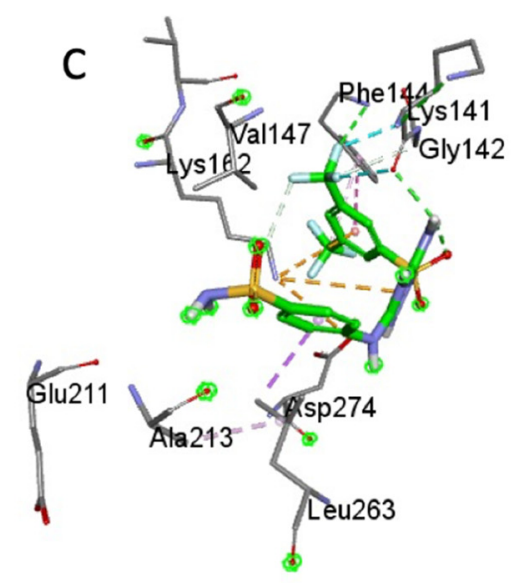

Figure 3. The molecular interactions of JNJ-7706621 (A), 1b (B) and 1d (C) with the ATP-binding site of Aurora-A kinase (PDB ID: 2W1C).

\section{Materials and Methods}

General method for the synthesis of compounds (1a-d):

The corresponding benzenesulfonyl chloride $(3.75 \mathrm{mmol})$ was added dropwise to a suspension of 4-((3-amino-1H-1,2,4-triazol-5-yl)amino)benzenesulfonamide (5) (3.75 mmol) in anhydrous pyridine $(3 \mathrm{~mL})$. The reaction was stirred at RT overnight. The compounds were then purified either by flash chromatography or by recrystallization from a suitable solvent system. 
4-((5-amino-1-(phenylsulfonyl)-1H-1,2,4-triazol-3-yl)amino) benzenesulfonamide (1a): column chromatography, Silica Gel, Hexane-EtOAc (30:70). Yield: 34\%. white solid (MP: 229-231 $\left.{ }^{\circ} \mathrm{C}\right) .{ }^{1} \mathrm{H}$ NMR (300 MHz, DMSO-d6): 9.70 (s, 1H), 7.99 (d, J = 8.3 Hz, 2H), 7.78 $(\mathrm{s}, 1 \mathrm{H}), 7.69(\mathrm{~d}, J=8.6 \mathrm{~Hz}, 4 \mathrm{H}), 7.60-7.46(\mathrm{~m}, 3 \mathrm{H}), 7.15(\mathrm{~s}, 2 \mathrm{H}) .{ }^{13} \mathrm{C}$ NMR $(75 \mathrm{MHz}, \mathrm{DMSO}-$ d6): 159.77, 157.88, 143.97, 136.32, 135.68, 135.44, 130.19, 127.88, 127.24, 116.39. LC/MS (ESI+) $\mathrm{m} / \mathrm{z}$ [M + 1] calculated: 395.06, found: 395.44. Elemental analysis, calculated (\%): C, 42.63; H, 3.58; N, 21.31; S, 16.26, found (\%): C, 43.01; H, 3.56; N, 21.12; S, 15.98.

4-((5-amino-1-((2,6-difluorophenyl)sulfonyl)-1H-1,2,4-triazol-3-yl)amino) benzenesulfonamide (1b): column chromatography, Silica Gel, Hexane-EtOAc (30:70). Yield: $18.6 \%$. White solid (MP: $\left.224-226{ }^{\circ} \mathrm{C}\right) .{ }^{1} \mathrm{H}$ NMR (300 MHz, DMSO-d6): 10.97 (s, 1H), $7.87(\mathrm{~d}, J=8.3 \mathrm{~Hz}, 2 \mathrm{H}), 7.73(\mathrm{~d}, J=8.3 \mathrm{~Hz}, 2 \mathrm{H}), 7.58(\mathrm{~d}, J=8.3 \mathrm{~Hz}, 2 \mathrm{H}), 7.52-7.39(\mathrm{~m}, 1 \mathrm{H})$, 7.08 (s, 2H), $5.63(\mathrm{~s}, 2 \mathrm{H}) .{ }^{13} \mathrm{C}$ NMR $\left(75 \mathrm{MHz}, \mathrm{DMSO}-\mathrm{d}_{6}\right): 159.87,159.46$ (d, $\left.J=255.8 \mathrm{~Hz}\right)$, $157.75,157.47,143.92,138.78,135.81,127.14,116.36,114.50,114.20$. LC/MS (ESI+) m/z [M + 1] calculated: 431.04, found: 431.46. Elemental analysis, calculated (\%): C, 39.07; H, $2.81 ; \mathrm{F}, 8.83 ; \mathrm{N}, 19.53 ; \mathrm{S}, 14.90$, found (\%): C,39.42; H, 2.76; N, 19.13; S, 14.51; F, 8.54.

4-((5-amino-1-tosyl-1H-1,2,4-triazol-3-yl)amino)benzenesulfonamide (1c): column chromatography, Silica Gel, $\mathrm{CH}_{2} \mathrm{Cl}_{2}$ (100\%). Yield: $3.4 \%$. White solid ${ }^{1} \mathrm{H} \mathrm{NMR} \mathrm{(300} \mathrm{MHz,}$ DMSO-d6): 9.68 (s, 1H), $7.86(\mathrm{~d}, J=9.0 \mathrm{~Hz}, 2 \mathrm{H}), 7.77(\mathrm{~d}, J=8.2 \mathrm{~Hz}, 2 \mathrm{H}), 7.56(\mathrm{~m}, 6 \mathrm{H}), 7.13$ (s, 2H), 6.10 (s, 2H), 2.36 (s, 3H). ${ }^{13} \mathrm{C}$ NMR $\left(75 \mathrm{MHz}, \mathrm{DMSO}-d_{6}\right) \delta 159.70,157.87,146.35,143.99$, 135.63, 133.39, 130.60, 127.91, 127.23, 116.35, 21.58. LC/MS (ESI+) m/z [M + 1] calculated: 409.08, found: 409.47. Elemental analysis, calculated (\%): C, 44.11; H, 3.95; N, 20.58; S, 15.70., found (\%): C, 44.17; H, 3.89; N, 20.29; S, 15.55 .

4-((5-amino-1-((3,5-bis(trifluoromethyl)phenyl)sulfonyl)-1H-1,2,4-triazol-3-yl)amino) benzenesulfonamide (1d): recrystallized from acetone. Yield: 36.97\%. White solid (MP: 241.6-243 ${ }^{\circ} \mathrm{C}$ ). ${ }^{1} \mathrm{H}$ NMR (300 MHz, DMSO-d6): 9.78 (s, $\left.1 \mathrm{H}\right), 8.59$ (d, J = 9.2 Hz, 2H), 7.67 $(\mathrm{d}, \mathrm{J}=8.9 \mathrm{~Hz}, 2 \mathrm{H}), 7.53(\mathrm{~d}, J=8.9 \mathrm{~Hz}, 1 \mathrm{H}), 7.16(\mathrm{~s}, 2 \mathrm{H}) .{ }^{13} \mathrm{C}$ NMR $(75 \mathrm{MHz}, \mathrm{DMSO}-\mathrm{d} 6) \delta$ $160.41,158.00,143.67,138.30,136.10,132.36,131.91,127.19,124.55$ (q, $J=255.8 \mathrm{HZ}), 116.5$. LC/MS (ESI+) m/z [M + 1] calculated: 530.04, found: 531.51 elemental analysis, calculated (\%): C, 36.23; H, 2.28; F, 21.49; N, 15.84; S, 12.09, found (\%): C, 36.29; H, 2.14; F, 21.40; N, $15.97 ;$ S, 11.97.

Biochemical assay:

JNJ-7706621and compounds 1a-c were prepared as a $5 \times$ stock solution in DMSO. The compounds were then tested in a 10-dose $\mathrm{IC}_{50}$ mode, with 3-fold serial dilutions at a starting concentration of $100 \mu \mathrm{M}$. The assay kinase buffer was used to dilute the Aurora-A kinase to a final concentration of $1.25 \mathrm{nM}$. The assay reaction was initiated by the addition of freshly prepared master mix to all wells (reaction, control, and blank) to achieve the following final concentrations: $1.25 \mathrm{nM}$ Aurora-A kinase, $10 \mu \mathrm{M}$ CSox-peptide substrate, $15 \mu \mathrm{M}$ ATP, and $1 \mathrm{mM}$ DTT in a final reaction volume of $50 \mu \mathrm{L}$ per well. The reaction wells were mixed, and the relative fluorescence unit (RFU) data were collected every 3 min for $30 \mathrm{~min}$ at $30{ }^{\circ} \mathrm{C}$. The used $\lambda_{\mathrm{Ex} / \mathrm{Em}}$ of the chelated $\mathrm{Mg}^{2+}$ with the Sox was $360 / 485 \mathrm{~nm}$.

Molecular docking:

In this study, Aurora-A kinase co-crystallized with 4-fluoro-N-(3-(5-(morpholinomethyl)1H-benzo[d]imidazol-2-yl)-1I-pyrazole-4-yl) benzamide (PDB ID 2W1C) was used. This pyrazole-benzimidazole derivative displayed the main binding interactions with the ATPpocket required to design a classical Aurora-A kinase inhibitor. The re-docking studies were performed for the crystal structure 2W1C as a validation method. AutoDock tools [13] were used to process the enzyme. PyRx [14] was used to perform the docking. Discovery Studio Visualizer [15] was used to visualize and access the docking results.

\section{Conclusions}

This work reported the development of new triazole derivatives as Aurora-A kinase inhibitors. The new compounds displayed important inhibitory activity, as attested by 
their $\mathrm{IC}_{50} \mathrm{~s}$ in the low to submicromolar range. These new derivatives represent promising inhibitors that can be considered for further investigations.

Funding: This research was funded by Deanship of Scientific Research at Umm Al-Qura University, Grant Number 19-MED-1-01-0041.

Institutional Review Board Statement: Not applicable.

Informed Consent Statement: Not applicable.

Data Availability Statement: The data presented in this study are available within this article.

Acknowledgments: The author would like to thank the deanship of Scientific Research at Umm Al-Qura University for supporting this work (Grant Code: 19-MED-1-01-0041).

Conflicts of Interest: The author declare that they have no competing interests.

Sample Availability: Not available.

\section{References}

1. Lengauer, C.; Kinzler, K.W.; Vogelstein, B. Genetic instabilities in human cancers. Nature 1998, 396, 643-649. [CrossRef] [PubMed]

2. Neuse, C.J.; Lomas, O.C.; Schliemann, C.; Shen, Y.J.; Manier, S.; Bustoros, M.; Ghobrial, I.M. Genome instability in multiple myeloma. Leukemia 2020, 34, 2887-2897. [CrossRef] [PubMed]

3. Willems, E.; Dedobbeleer, M.; Digregorio, M.; Lombard, A.; Lumapat, P.N.; Rogister, B. The functional diversity of Aurora kinases: A comprehensive review. Cell Div. 2018, 13, 7. [CrossRef] [PubMed]

4. Bavetsias, V.; Linardopoulos, S. Aurora Kinase Inhibitors: Current Status and Outlook. Front. Oncol. 2015, 5, 278. [CrossRef] [PubMed]

5. D'Assoro, A.B.; Haddad, T.; Galanis, E. Aurora-A Kinase as a Promising Therapeutic Target in Cancer. Front. Oncol. 2015, 5, 295. [CrossRef] [PubMed]

6. Kitzen, J.J.; de Jonge, M.J.; Verweij, J. Aurora kinase inhibitors. Crit. Rev. Oncol. Hematol. 2010, 73, 99-110. [CrossRef] [PubMed]

7. Emanuel, S.; Rugg, C.A.; Gruninger, R.H.; Lin, R.; Fuentes-Pesquera, A.; Connolly, P.J.; Wetter, S.K.; Hollister, B.; Kruger, W.W.; Napier, C.; et al. The in vitro and in vivo effects of JNJ-7706621: A dual inhibitor of cyclin-dependent kinases and aurora kinases. Cancer Res. 2005, 65, 9038-9046. [CrossRef] [PubMed]

8. Rodland, G.E.; Melhus, K.; Generalov, R.; Gilani, S.; Bertoni, F.; Dahle, J.; Syljuasen, R.G.; Patzke, S. The Dual Cell Cycle Kinase Inhibitor JNJ-7706621 Reverses Resistance to CD37-Targeted Radioimmunotherapy in Activated B Cell Like Diffuse Large B Cell Lymphoma Cell Lines. Front. Oncol. 2019, 9, 1301. [CrossRef] [PubMed]

9. Vijayadas, K.N.; Davis, H.C.; Kotmale, A.S.; Gawade, R.L.; Puranik, V.G.; Rajamohanan, P.R.; Sanjayan, G.J. An unusual conformational similarity of two peptide folds featuring sulfonamide and carboxamide on the backbone. Chem. Commun. 2012, 48, 9747-9749. [CrossRef] [PubMed]

10. Lin, R.; Connolly, P.J.; Huang, S.; Wetter, S.K.; Lu, Y.; Murray, W.V.; Emanuel, S.L.; Gruninger, R.H.; Fuentes-Pesquera, A.R.; Rugg, C.A.; et al. 1-Acyl-1H-[1,2,4]triazole-3,5-diamine analogues as novel and potent anticancer cyclin-dependent kinase inhibitors: Synthesis and evaluation of biological activities. J. Med. Chem. 2005, 48, 4208-4211. [CrossRef] [PubMed]

11. Beck, J.R.; Peterson, L.B.; Imperiali, B.; Stains, C.I. Quantification of protein kinase enzymatic activity in unfractionated cell lysates using CSox-based sensors. Curr. Protoc. Chem. Biol. 2014, 6, 135-156. [CrossRef] [PubMed]

12. Yan, A.; Wang, L.; Xu, S.; Xu, J. Aurora-A kinase inhibitor scaffolds and binding modes. Drug Discov. Today 2011, 16, 260-269. [CrossRef] [PubMed]

13. Morris, G.M.; Huey, R.; Lindstrom, W.; Sanner, M.F.; Belew, R.K.; Goodsell, D.S.; Olson, A.J. AutoDock4 and AutoDockTools4: Automated docking with selective receptor flexibility. J. Comput. Chem. 2009, 30, 2785-2791. [CrossRef] [PubMed]

14. Dallakyan, S.; Olson, A.J. Small-molecule library screening by docking with PyRx. Methods Mol. Biol. 2015, 1263, $243-250$. [CrossRef] [PubMed]

15. BIOVIA, Dassault Systèmes. Discovery Studio Modeling Environment; Dassault Systèmes: San Diego, CA, USA, 2017. 